\title{
Influence of Phosphorus Fertilizer on Potato Seed Production in Acid Soils in Kenya
}

\author{
Evans Mutange Akoto ${ }^{1}$, Caleb O. Othieno ${ }^{2} \&$ Julius O. Ochuodho ${ }^{3}$ \\ ${ }^{1}$ Ministry of Agriculture, Livestock Development, Fisheries \& Cooperatives, Nairobi, Kenya \\ ${ }^{2}$ Department of Soil Science, University of Eldoret, Kenya \\ ${ }^{3}$ Department of Crops, Seed and Horticultural sciences, University of Eldoret, Kenya \\ Correspondence: Evans Mutange, Ministry of Agriculture, Livestock Development, Fisheries and Cooperatives, \\ Nairobi, Kenya. Tel: 254-718-796-253. E-mail: akotomutange@ gmail.com
}

Received: March 1, $2020 \quad$ Accepted: April 1, $2020 \quad$ Online Published: April 12, 2020
doi:10.5539/sar.v9n2p101
URL: https://doi.org/10.5539/sar.v9n2p101

\begin{abstract}
One of the major challenges facing potato (Solanum Tuberosum L) production in Kenya is the inadequate supply of high-quality seed. The required amount of potato seed in Kenya is about 70,000 tones annually but, only $1 \%$ is available. Otherwise, farmers use low quality farm saved seed (KEPHIS, 2016). A major contributor to this situation is low and declining soil fertility, particularly phosphorus, among other challenges. Unfortunately, there is no available phosphorus fertilizer rate recommendation for seed potato production in Kenya. This hinders economic utilization of phosphorus fertilizers to achieve optimal production of quality potato seed in Kenya where its deficiencies are dominant. Therefore, this study investigated influence of different rates of phosphorus fertilizer on seed potato tuber yield and quality in three acidic $(\mathrm{pH} \leq 5.8)$ test sites: Lari, Ainabkoi and Saboti sub Counties. Unica and Shangi varieties were tested. The field experiment was a split plot arrangement in Randomised Complete Block Design (RCBD) with six treatments (0 N \& 0 P), 0, 30, 60, 90 and $120 \mathrm{~kg} \mathrm{ha}^{-1}$ phosphorus, replicated three times. Data collected included tuber weight, number of tubers, tuber grade, number of eyes per tuber, tuber specific density and final germination percentage. To monitor soil nutrient dynamics, soil $\mathrm{pH}$, soil available phosphorus, total nitrogen, total carbon, potassium, calcium, magnesium, copper, iron, zinc, sodium and exchangeable acidity (Lari only) were determined at planting while available phosphorus and potato tuber phosphorus were determined at harvesting. Data was statistically analysed using ANOVA at $5 \%$ confidence levels with General Statistics (GENSTAT) and excel softwares. Results indicated that phosphorus rate significantly influenced seed tuber yield in the test sites. At Saboti, (ON \& 0P) and no phosphorus application treatments for Shangi and Unica resulted in the highest seed tuber yield of $33.7 \mathrm{tha}^{-1}$ and $33.2 \mathrm{t} \mathrm{ha}^{-1}$, respectively. At Ainabkoi, application of $60 \mathrm{~kg} \mathrm{ha}^{-1}$ and $30 \mathrm{~kg} \mathrm{ha}^{-1}$ phosphorus produced the highest seed tuber yields of $20.0 \mathrm{tha}^{-1}$ and $18.9 \mathrm{tha}^{-1}$ of Shangi and Unica, respectively. In Lari, application of $60 \mathrm{~kg} \mathrm{ha}^{-1}$ and $90 \mathrm{~kg}$ $\mathrm{ha}^{-1}$ phosphorus produced the highest seed tuber yields of $19.0 \mathrm{t} \mathrm{ha}^{-1}$ and $10.4 \mathrm{t} \mathrm{ha}^{-1}$ of Shangi and Unica, respectively. Unica had better final germination percentage than Shangi. During the season, there was a build-up of soil available phosphorus. Thus, there is need for farmers to test their soils at the onset of every potato season.
\end{abstract}

Keywords: seed yield, specific density, germination percentage, soil available phosphorus, tuber phosphorus, "ware" potato

\section{Introduction}

Potato (Solanum tuberosum $L$ ) is the second most important food crop after maize in Kenya and also the world's most important tuber crop grown in more than 150 countries (FAO, 2019; Wang, 2008). It originated from Andes, in South America (FAO, 2008), was taken to Ireland and later introduced into Kenya by the white settlers in 1880s (Spooner et al., 2005). In Kenya, it is commonly called "Irish potato" because it was the main crop grown in Ireland in 1800s when the country was hard hit by the great Irish famine that was the worst agricultural, social and cultural disasters of the time that claimed one out of eight million people (FAO, 2008). It was grown for the first time in Kiambu, Nyeri and Muranga counties (NPCK, 2016). About 800,000 farmers (Out of which 500, 000 are small scale) grow potatoes mainly in five counties (Nyandarua, Uasin-Gishu, Meru, Nakuru and Nandi) on about 192,341 ha (FAO, 2019; Shawiza, 2017). 
Potato is a food and cash crop with multipurpose domestic and industrial uses. Domestic uses include consumption as french fries, bhajia, crisps and mashed potato as well as livestock feed while industrial uses include production of starch, soap and ethanol (KEPHIS, 2016). It is a good source of carbohydrate; protein; vitamin B1, B3, B6 and C; fibre; iron; zinc and potassium. It is also naturally low in fat, cholesterol and sodium with antioxidants properties, making it healthy for human consumption (Duroy et al., 2009). Thus, it greatly contributes to alleviating poverty, food and nutritional insecurity (Abong'o \& Kabira, 2013).

Potato grows best in altitudes of 1500 to $3000 \mathrm{~m}$ above sea level (KEPHIS, 2016). However, with proper management and proper use of technology, the crop can grow well in lower altitude areas (Lutaladio et al., 2009). Rainfall of about $750 \mathrm{~mm}$ and optimal temperatures of between $15{ }^{\circ} \mathrm{C}$ and $20{ }^{\circ} \mathrm{C}$ are required during the growing period (KEPHIS, 2016 \& MOA, 2011).

The crop requires well drained, high organic matter, fertile and loam textured soils with $\mathrm{pH}$ ranging 4.5 to 8.5 . However, seed potato does best at pH between 5.5 and 7.0 (MOA, 2011 and KEPHIS, 2016). The major nutritional requirements of the crop are potassium $(\mathrm{K})$, nitrogen $(\mathrm{N})$ and phosphorus $(\mathrm{P})$. It is suggested to have the three nutrients in the ratio of 1:1:1 to avoid spoiling tuber quality (Lutaladio et al., 2009). In 2017, Kenya with a production of about 1.52 million tones was the $6^{\text {th }}$ best African country in potato production after Algeria, Egypt, South Africa, Morocco and Tanzania. Between 2007 and 2017, on average, Kenya's area under production, yield and total annual production were 135,677 ha, $16.6 \mathrm{t} \mathrm{ha}^{-1}$ and 2.3 million tones, respectively. In the same period, area under potato production increased by about 56,664 ha. However, potato yield declined by about $8.7 \mathrm{t} \mathrm{ha}^{-1}$ in the same period (FAO, 2019). This could be caused by the many challenges facing potato production which include high incidences of pests and diseases; weak research-extension linkage; poor market infrastructure; declining soil fertility; use of low quality and/or low supply of clean and certified seed (Muthoni, 2016; Karanja et al., 2014).

Potato seed accounts for between 35 and $50 \%$ of the production costs (Lutaladio et al., 2009). Currently, the demand for seed stands at about 70,000 metric tones against a supply of $1 \%$ of clean seed (KEPHIS, 2016). Thus, 98\% of the farmers use farm saved seed which are characterized by low quality (Janessens et al., 2013). Hence, there is great need for rapid interventions to improve seed production and quality in Kenya. Unfortunately, this is hindered by erratic rainfall, pests, diseases and most importantly low and declining soil fertility (Karanja et al., 2014).

The art of seed potato production in Kenya is guided by Chapter 326 (Seed and plant varieties Act) of the laws of Kenya (NPCK, 2018). It is regulated by a state parastatal known as Kenya Plant Health Inspectorate Service (KEPHIS). Besides KEPHIS, other important players on the seed potato value chain include researchers, breeders, seed multipliers, "ware" potato producers, consumers, traders, transporters, processors and extensionists (NPCK, 2018). The number of authorized seed potato producers in Kenya increased from 12 in 2013 to 27 in 2019 while the number of documented potato varieties increased from 13 in 2013 to 60 in 2019 (NPCK, 2013 \& NPCK, 2019). Since 2005, a special arrangement has been made to encourage small scale farmers to produce certified seed. Interested farmers affiliate to registed seed companies (KEPHIS, 2016). They are monitored by Ministry of Agriculture, KEPHIS, Kenya Agricultural Research Organization (KALRO) and the seed companies (NPCK, 2018). The process of certified seed potato production begins with breeders who select True Potato Seeds. They plant the seeds which produce different cultivars. Apical cuttings or minitubers from preferred cultivars are multiplied using pots, hydroponics or aeroponic techniques. The first generation of the breeder's seed is known as prebasic seed while the second generation is known as basic seed (NPCK, 2018). Certified seed is seed multiplied from basic seed up to the third generation. Basic seed is not only breeded in Kenya but also imported from other countries like Netherlands (NPCK, 2018). The procedures for availing certified seed involves registration of actors or dealers; performance trials; testing new varieties; release and gazettment of new varieties; seed multiplication; field inspection and seed testing (Hort, 2018). There exits informal techniques of improving seed potato production in Kenya which are positively selected and negatively selected seed potato production (KEHIS, 2016).To avoid buildup of seed and soil born diseases particularly bacteria wilt, seed farmers are encouraged to practice crop rotation (NPCK, 2019).

Fertilizers used by seed multipliers are mostly inorganic and mainly diamonium phosphate (DAP). It is recommended that the amount of fertilizer applied on seed potato be less than that which is applied on "ware" potato because of their smaller size and shorter maturation period (KEPHIS, 2016). Deficiency of phosphorus has been reported in major potato producing areas in Kenya (Muthoni, 2016; NAAIAP, 2014). This could impact negatively on the potato seed quality and yields. The nutrient affect tuber skin setting; dry matter accumulation; time to maturity; storage quality of tubers; tuber size and tuber protein, nitrate and reducing sugar content (Tuhin et al., 2007; Lutaladio et al., 2009; Muthoni, 2016;). However, none of the present fertilizer recommendations in 
Kenya focus on providing the right fertilizer rates for seed potato production. Therefore, this research focused on influence of application of phosphorus fertilizer on seed potato tuber yield and quality in Lari, Ainabkoi and Saboti Sub Counties.

The broad objective of the study was to increase potato seed production in Kenya through enhanced soil fertility particularly phosphorus in the main potato producing sub - counties of Kenya while its specific objective was to determine influence of phosphorus rate on seed potato tuber yield and quality.

\section{Materials and Methods}

\subsection{Description of Study Sites}

This study was carried out in three locations: Saboti, Ainabkoi and Lari (Figure 1). Saboti $\left(0.94{ }^{\circ} \mathrm{N}, 34.84{ }^{\circ} \mathrm{E}\right)$ is in Trans Nzoia County at an elevation of $1923 \mathrm{~m}$ above sea level. Its soils are humic nitosols while its agro ecological zone is Upper midland (Maize and coffee zone). It receives 1000 to $1200 \mathrm{~mm}$ of rainfall annually and has temperature range of 10 to $27^{\circ} \mathrm{C}$. Ainabkoi $\left(0.18^{\circ} \mathrm{N}, 35.53^{\circ} \mathrm{E}\right)$ is in Uasin Gishu County at an altitude of $2300 \mathrm{~m}$ above sea level. Its agro ecological zone is Upper Highland Zone 2 (UH2) which is a pyrethrum and wheat zone. The area receives annual rainfall of about 1200 to $1400 \mathrm{~mm}$. Its annual temperature ranges between 13.3 to $15.7{ }^{\circ} \mathrm{C}$. Its soil type is humic Nitisols. Lari $\left(1.11^{\circ} \mathrm{S}, 36.64{ }^{\circ} \mathrm{E}\right)$ is in Kiambu County. It has an elevation of $2550 \mathrm{~m}$ above sea level, annual rainfall of $1400 \mathrm{~mm}$, temperature of 12 to $21^{\circ} \mathrm{C}$ and an agro ecological zone of Upper highland 1 (Pyrethrum and Dairy zone). Its soils are planosols (NAIAAP, 2014; Jaetzold and Schmidt, 2009; Jaetzold et al., 2011).

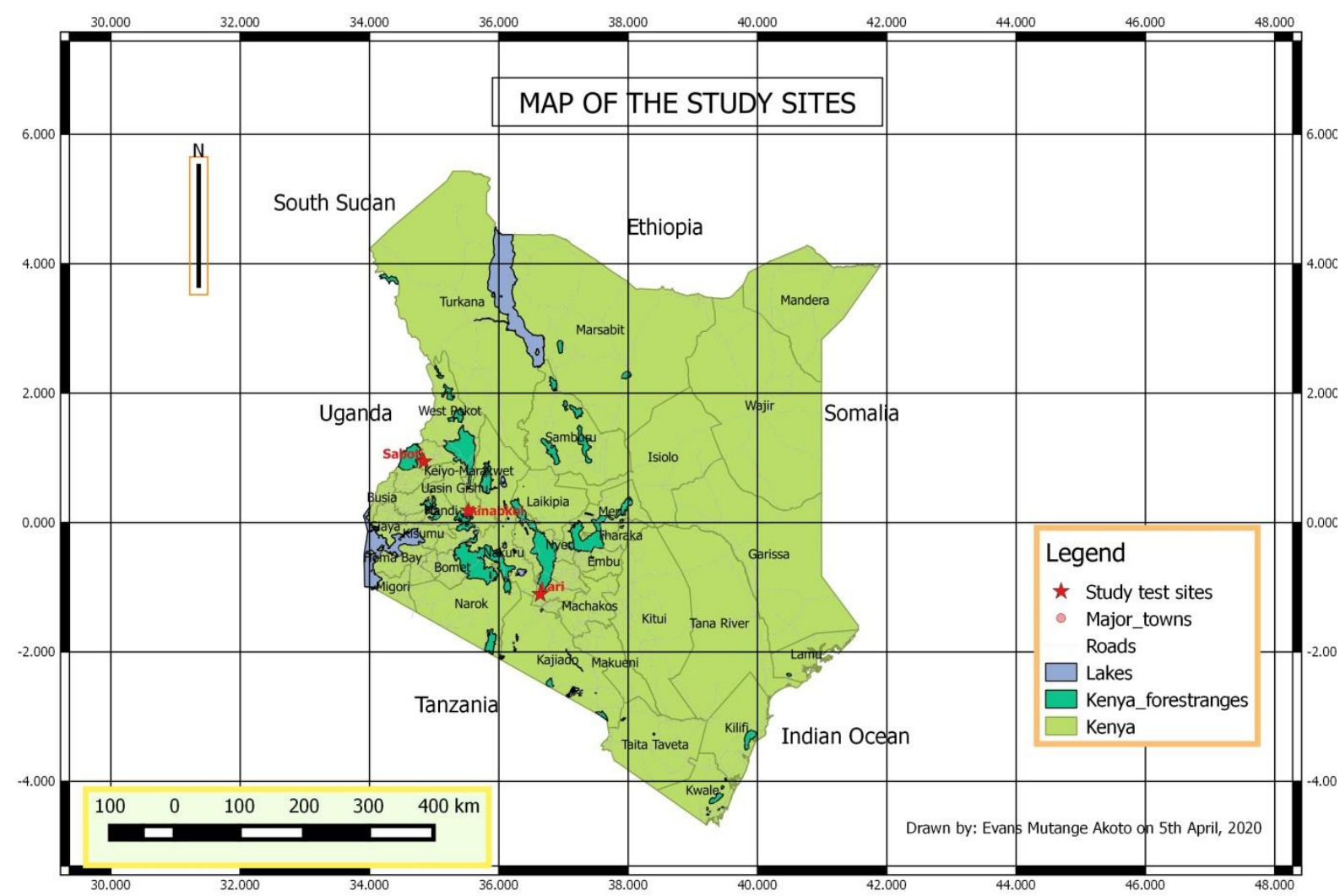

Figure 1. Location of the study sites (Source: First hand data by GPS machine; ILRI (2015) and Open Africa (2020)

\subsection{Test Potato Varieties}

The test potato varieties that were grown were Unica and Shangi. Unica was selected based on its high yielding potential $\left(>45 \mathrm{tha}^{-1}\right.$ ) and suitability for chips, crisps and domestic uses (NPCK, 2019). It is also rich in vitamin $\mathrm{C}$, iron and zinc. Shangi was selected based on its popularity with farmers and its local availability. Unica is an alternative to Shangi which has short storage time (NPCK, 2019). 


\subsection{Experimental Treatments and Coding}

In each test site, nitrogen was applied at planting as a basal fertilizer at the rate of $90 \mathrm{~kg}$ nitrogen $\mathrm{ha}^{-1}$ as urea. Phosphorus was also applied at the same time at the rate of $0,30,60,90,120 \mathrm{~kg}_{\text {phosphorus }} \mathrm{ha}^{-1}$ as tripple supper phosphate (TSP). No fertilizer treatments (denoted IC) were also provided for in the study. The Nitrogen rate of $90 \mathrm{~kg} \mathrm{ha}^{-1}$ and phosphorus rate of $90 \mathrm{~kg} \mathrm{ha}^{-1}$ are documented by the National Potato Council of Kenya (Kaguongo et al., 2008 \& NPCK, 2013); Ministry of Agriculture, Livestock development, Fisheries and Cooperatives (MOA, 2011) and Kenya Agricultural and Livestock Research Organization ( KARI, 2008). These are general recommendations for "ware" potato production in Kenya. They are supported by Lutaladio (2009) who recommends nitrogen: phosphorus ratio of 1:1 for potato production. The rates for seed potato production are yet to be documented. Potassium was not tested since it was found to be at adequate level in the test sites (NAAIAP, 2014). Also, soil tests done at planting on the soils of the test sites indicated that the level potassium was high or adequate (Table $1 \& 4$ ).

Table 1. Phosphorus (P) fertilizer treatments and coding

\begin{tabular}{|c|c|c|c|}
\hline \multirow{2}{*}{$\begin{array}{l}\text { Treatment } \\
\text { Number }\end{array}$} & \multicolumn{2}{|l|}{ Description } & \multirow[b]{2}{*}{ Code } \\
\hline & $\begin{array}{l}\text { Rates of phosphorus } \\
\text { kg ha }^{-1}\end{array}$ & $\begin{array}{l}\text { Rates per plant: } \boldsymbol{T S P}=0.093 \times \text { Pgrams per plant }(\mathrm{P} \text { in } \mathrm{kg} / \\
\text { ha) } \text { Urea }=0.041 \mathrm{~N} \text { grams perplant }(\mathrm{N} \text { in } \mathrm{kg} / \mathrm{ha})\end{array}$ & \\
\hline 1 & $0 \mathrm{~N}, \mathrm{OP}$ & $0 \mathrm{~g}$ Urea, $0 \mathrm{~g}$ TSP per plant & IC \\
\hline 2 & OP & $0 \mathrm{~g}$ TSP per plant & P0 \\
\hline 3 & $30 \mathrm{~kg} \mathrm{P} \mathrm{ha}^{-1}$ & $2.8 \mathrm{~g}$ TSP per plant & $\mathrm{P} 1$ \\
\hline 4 & $60 \mathrm{~kg} \mathrm{P} \mathrm{ha}^{-1}$ & $5.6 \mathrm{~g}$ TSP per plant & $\mathrm{P} 2$ \\
\hline 5 & $90 \mathrm{~kg} \mathrm{P} \mathrm{ha}^{-1}$ & 8.4. g TSP per plant & P3 \\
\hline 6 & $120 \mathrm{~kg} \mathrm{P} \mathrm{ha}^{-1}$ & $11.2 \mathrm{~g}$ TSP per plant & P4 \\
\hline
\end{tabular}

Basal application of nitrogen at $90 \mathrm{~kg} \mathrm{ha}^{-1}(3.6 \mathrm{~g}$ Urea per plant) was applied to all plants except in the IC (0N, OP) plots.

\subsection{Experimental Layout}

The experimental lay out had 36 experimental units in three blocks, two treatments of variety (Main plot treatments) and six sub plot treatments (Table 2).

Table 2. Experimental layout

\begin{tabular}{llllll}
\hline \multicolumn{2}{l}{ Block 1 } & \multicolumn{2}{l}{ Block 2 } & \multicolumn{2}{l}{ Block 3 } \\
\hline \multicolumn{2}{l}{ Main plots: Varieties } & \multicolumn{2}{l}{ Main plots: Varieties } & \multicolumn{2}{l}{ Main plots: Varieties } \\
\hline Unica & Shangi & Shangi & Unica & Unica & Shangi \\
\hline P0 & P2 & IC & P3 & P4 & P1 \\
P4 & IC & P0 & P2 & P3 & P4 \\
P1 & P3 & P4 & IC & P2 & P0 \\
P3 & P4 & P2 & P1 & P0 & IC \\
IC & P0 & P1 & P4 & P1 & P2 \\
P2 & P1 & P3 & P0 & IC & P3 \\
\hline
\end{tabular}

\subsection{Soil Sampling and Seed Bed Preparation.}

Land was ploughed before the onset of rains and sub divided into 36 experimental units. The size of each unit was $4 \mathrm{~m}$ by $3 \mathrm{~m}$ surrounded by $1 \mathrm{~m}$ wide path. The total area needed for the study was therefore 0.23 ha per site. Soil samples were obtained before planting and after harvesting. Two composite soil samples $(0-15 \mathrm{~cm}$ and $15-30 \mathrm{~cm})$ were taken in grid style before planting. Further, soil samples $(0-15 \mathrm{~cm})$ were taken at harvesting in grid style in each experimental unit. Any time the samples were taken, they were transferred to clearly labeled "Khaki" bags and stored in the greenhouse for 14 days for air drying before their analysis.

\subsection{Planting, Ridging, Weeding, Diseases and Pests Management}

The seed used for planting was of good quality. It was large grade ( $45 \mathrm{~mm}$ to $60 \mathrm{~mm}$ diameter). It was planted at a spacing of $75 \mathrm{~cm}$ between rows and $25 \mathrm{~cm}$ within rows. Planting was done at the onset of long rains in the three sites where fertilizers were well worked in the soil. Well sprouted seed tubers were then placed in the furrow and covered with soil immediately. Fertilizers were applied according to the treatment plan (Table $1 \& 2$ ). Ridging (earthing up) and weeding were done concurrently at 30 to 45 days after planting. To maintain quality tubers, undesirable plants were roughed out. Pesticides and fungicides were applied according to need to control 
pests and diseases.

\subsection{Dehaulming, Harvesting and Post-harvest Handling}

The size of the seed potato tubers were monitored to avoid them becoming too big for seed. When the plant tops started to turn yellow (physiological maturity) and $60 \%$ to $70 \%$ of the tubers were in the seed size grade ( 28 $\mathrm{mm}$ to $60 \mathrm{~mm}$ ), the above ground biomass was cut (dehaulmed) and left for two weeks for tuber skin to harden before harvesting (KEPHIS, 2016). Harvesting was done in the morning and late in the afternoon when temperatures were warm and soils were moist but not wet to minimise scorching of tubers caused by the bright sunlight. The harvest of the two end rows and the last two plants per raw were separated from the rest before storage since it was not used in data analysis. Seed potatoes were stored at ambient temperatures in open diffused light storages (MOA, 2011) for data collection.

\subsection{Potato Yield Data}

Potato tuber yields under the following classes: $<28 \mathrm{~mm} ; 28 \mathrm{~mm}-45 \mathrm{~mm} ; 46 \mathrm{~mm}-60 \mathrm{~mm}$ and $>60 \mathrm{~mm}$ were determined using equation 1 . The classes are based on KEPHIS (2016) guidelines.

$$
\mathrm{G}_{1}=\frac{100000}{0.25 \times 0.75 \times 1000} \times \mathrm{Y}
$$

Where: $\mathrm{G}_{1}=$ Yield $\left(\mathrm{t} \mathrm{ha}^{-1}\right)$; $\mathrm{Y}=$ Average yield $(\mathrm{kg})$ of tubers from sampled plants = Weight $(\mathrm{kg})$ of sampled plants' tubers /Number of plants sampled (18 plants)

\subsection{Drying, Curing, Sorting and Grading of Seed Potatoes}

The harvested potatoes were dried quickly to remove excess water from the surface and improve their tuber conservation quality. The tubers were dried in a storage shed to avoid tuber greening. They were also sheltered from rain and water runoff. Since there were few of damaged and diseased potatoes, sorting was minimally done. Using calibrated grading boxes, seed potato tubers whose diameter ranged between $28 \mathrm{~mm}$ and $60 \mathrm{~mm}$ were graded. Further sample seed potatoes (two per test plot) were chopped into small pieces and air dried in the greenhouse for the determination of plant (tuber) phosphorus.

\subsection{Data on Seed Quality}

The data that was collected on seed quality included three parameters: final germination percentage, seed tuber specific density and number of eyes per tuber.

$$
\text { Final germination percentage }=\frac{\text { Number of planted and survived bushes }}{\text { Total number of tubers planted }} \times 100 \%
$$

Where: A bush is a collection of all plants growing from a planted potato tuber.

Seed specific density: Seed specific density of each category was calculated using weight (g) of tubers in air (Wa) and water (Ww) according to equation 3

$$
\text { Specific density }\left(\mathrm{g} \mathrm{g}^{-1}\right)=\frac{W a}{W a-W w}
$$

(Agriculture Victoria, 2010)

Number of eyes per tuber: The number of eyes of five sample large grade tubers per experimental plot were counted and dived by five to get the average number of eyes per tuber. The recommended number of eyes is 4 to 6 eyes (KEPHIS, 2016).

\subsection{Laboratory Analysis}

Soil samples at planting were analysed at the National Agricultural Research Laboratories (NARL) using Mehlich 3 protocal which extracts soil nutrients using double acid decomposition. They were analysed for $\mathrm{pH}$, available phosphorus, total nitrogen, soil total organic carbon, exchangeable acidity (Lari only), potassium (K), calcium $(\mathrm{Ca})$, magnesium $(\mathrm{Mg})$, copper $(\mathrm{Cu})$, iron $(\mathrm{Fe})$, zinc $(\mathrm{Zn})$ and sodium $(\mathrm{Na})$ (Harova and Spejra, 2014); Agro Eco Lab (2016). Further soil samples taken at planting and harvesting were also analysed for available phosphorus using Bray 2 procedures as outlined by Okalebo et al. (2002). The Bray 2 extractant was a solution of $0.03 \mathrm{M}$ ammonium fluoride and $0.1 \mathrm{M}$ hydrochloric acid. Phosphorus in potato tubers was extracted using a digestion mixture of hydrogen peroxide + concentrated sulphuric acid + selenium powder + salicylic acid) at temperatures of $110{ }^{\circ} \mathrm{C}$ to $330{ }^{\circ} \mathrm{C}$. After extraction, the concentration of phosphorous in sample solutions was determined calorimetrically. 


\subsection{Statistical Analysis}

Statistical Analysis was executed by GENSTAT and Microsoft excel soft wares. The experimental design was a split plot in Randomised Complete Block Design (RCBD). The linear statistical model for the split-plot design is:

$$
\mathrm{Y}_{\mathrm{ijk}}=\mu+\mathrm{V}_{\mathrm{i}}+\mathrm{B}_{\mathrm{j}}+\varepsilon_{1(i \mathrm{j})}+\mathrm{P}_{(\mathrm{k})}+\mathrm{VP}_{(\mathrm{ik})}+\varepsilon_{2(\mathrm{ijk})}
$$

Where: $\mathrm{Y}_{\mathrm{ijk}}=$ Total effect; $\mu=$ Mean effect. $\mathrm{V}_{\mathrm{i}}=$ The $\mathrm{i}^{\text {th }}$ effect of variety $(\mathrm{V}) ; \mathrm{B}_{\mathrm{j}=}$ The $\mathrm{j}^{\text {th }}$ effect of blocks; $\varepsilon_{1(i \mathrm{j})}=$ Main plot error; $\mathrm{P}_{(\mathrm{k})}=$ The $\mathrm{k}^{\text {th }}$ effect of phosphorus $(\mathrm{P}) ; \mathrm{VP}_{(\mathrm{ik})}=$ Effect due to interaction between variety $(\mathrm{V})$ and phosphorus $(\mathrm{P})$ and $\varepsilon_{2(i \mathrm{jk})}=$ Split plot Error. The skeletal ANOVA table is indicated below (Table 3).

Table 3. Skeletal ANOVA table $(F$ cal $>F$ table or $p<0.05=>$ significant difference at $5 \%$ )

\begin{tabular}{llllll}
\hline SOV & df & SS & MS & Fcal & p-value \\
\hline Blocks or replications (B) & $\mathrm{b}-1=2$ & $\mathrm{~B}_{\mathrm{SS}}$ & $\mathrm{B}_{\mathrm{MS}}$ & $\mathrm{B}_{\mathrm{SS}} / \mathrm{E}_{\mathrm{MS}(\mathrm{a})}$ & By GENSTAT \\
Main plots : Varieties (V) & $\mathrm{v}-1=1$ & $\mathrm{~V}_{\mathrm{SS}}$ & $\mathrm{V}_{\mathrm{MS}}$ & $\mathrm{V}_{\mathrm{SS}} / \mathrm{E}_{\mathrm{MS}(\mathrm{a})}$ & By GENSTAT \\
Main plot Error (V x B) or Error (a) & $(\mathrm{b}-1)(\mathrm{v}-1)=2$ & $\mathrm{E}_{\mathrm{SS}(\mathrm{a})}$ & $\mathrm{E}_{\mathrm{MS}(\mathrm{a})}$ & & \\
Sub-plots: Phosphorus (P)rates & $\mathrm{p}-1=5$ & $\mathrm{P}_{\mathrm{SS}}$ & $\mathrm{P}_{\mathrm{MS}}$ & $\mathrm{P}_{\mathrm{sS}} / \mathrm{E}_{\mathrm{MS}(\mathrm{b})}$ & By GENSTAT \\
Variety (V) x Phosphorus (P)-rates & $(\mathrm{v}-1)(\mathrm{p}-1)=5$ & $\mathrm{VP}_{\mathrm{SS}}$ & $\mathrm{VP}_{\mathrm{MS}}$ & $\mathrm{VP}_{\mathrm{SS}} / \mathrm{E}_{\mathrm{MS}(\mathrm{b})}$ & By GENSTAT \\
Sub plot error V(P x B) or Error (b) & $\mathrm{v}(\mathrm{p}-1)(\mathrm{b}-1)=20$ & $\mathrm{E}_{\mathrm{SS}(\mathrm{b})}$ & $\mathrm{E}_{\mathrm{MS}(\mathrm{b})}$ & & \\
Total & $\mathrm{bvp}-1=35$ & $\mathrm{~T}_{\mathrm{SS}}$ & $\mathrm{T}_{\mathrm{MS}}$ & & \\
\hline
\end{tabular}

\section{Results and Discussion}

\subsection{Soil Characteristics of Test Sites Prior to Treatment Applications}

The chemical characterization of the top $0-15 \mathrm{~cm}$ soils from the test sites at planting showed that they were acidic. Lari with a pH of 4.6 was strongly acidic while Ainabkoi and Saboti with pH of 5.6 and 5.8 respectively were moderately acidic. The level of available soil phosphorus was low at Lari, adequate at Ainabkoi and high at Saboti. At all the test sites $(0-15 \mathrm{~cm}$ depth), potassium and total nitrogen were adequate. Soil zinc level was low in Lari but adequate in Saboti and Ainabkoi.Total organic carbon was moderate in Ainabkoi but adequate in Saboti and Lari. The exchangeable acidity was adequate in Lari (Table 4).

Table 4. Chemical and physical properties of the surface soils $(0-15 \mathrm{~cm}$ and $15-30 \mathrm{~cm})$ taken before planting (2019 long rains) at three experimental sites in Kenya (Bolded figures indicate low nutrient status)

\begin{tabular}{llllllll}
\hline Soil property & Critical value & Saboti & \multicolumn{3}{c}{ Ainabkoi } & Lari \\
\hline Depth of soil sample (cm) & N/A & $0-15$ & $15-30$ & $0-15$ & $15-30$ & $0-15$ & $15-30$ \\
Soil pH (1: 2.5 Soil: Water) & $\geq 5.5$ & 5.83 & 5.67 & 5.62 & 5.59 & $\mathbf{4 . 6}$ & $\mathbf{4 . 8 3}$ \\
Exchangeable acidity (me \%) & & & & & & 0.4 & 0.4 \\
Total nitrogen (\%) & $\geq 0.2$ & 0.34 & 0.30 & 0.24 & $\mathbf{0 . 1 8}$ & 0.25 & 0.24 \\
Total Organic carbon (\%) & $\geq 2.7$ & 3.55 & 3.13 & $\mathbf{2 . 5 4}$ & $\mathbf{2 . 0 1}$ & $\mathbf{2 . 7}$ & $\mathbf{2 . 5 1}$ \\
Phosphorus (ppm) & $\geq 30$ & 45 & 45 & 40 & 35 & $\mathbf{2 5}$ & $\mathbf{3 0}$ \\
Potassium (me \%) & $\geq 0.24$ & 1.00 & 0.41 & 2.03 & 2.03 & 0.71 & 0.69 \\
Calcium (me \%) & $\geq 2.0$ & 26.0 & 26.8 & 14.2 & 10.2 & $\mathbf{1 . 4}$ & $\mathbf{1 . 2}$ \\
Magnesium (me \%) & $\geq 1.0$ & 4.06 & 5.10 & 4.04 & 3.56 & $\mathbf{0 . 7 9}$ & $\mathbf{0 . 8 2}$ \\
Manganese (me \%) & $\geq 1.0$ & $\mathbf{0 . 9 6}$ & $\mathbf{0 . 6 2}$ & $\mathbf{0 . 6 4}$ & $\mathbf{0 . 6 7}$ & $\mathbf{0 . 4 8}$ & $\mathbf{0 . 3 6}$ \\
Copper (ppm) & $\geq 1.0$ & 9.83 & 9.71 & 2.50 & 2.15 & 2.4 & 2.1 \\
Iron (ppm) & $\geq 10$ & 16.1 & 17.2 & 16.2 & 17.8 & 220 & 224 \\
Zinc (ppm) & $\geq 5$ & $\mathbf{2 . 4 6}$ & $\mathbf{1 . 4 0}$ & $\mathbf{4 . 3 1}$ & $\mathbf{3 . 8 4}$ & 8.58 & 5.29 \\
Sodium (me \%) & N/A & 0.50 & 0.54 & 0.50 & 0.48 & 0.62 & 0.86 \\
Soil colour & N/A & Dark & Dark reddish & Dark & Reddish & Grey & Greyish \\
& & brown & brown & brown & brown & & Red \\
Stickness & N/A & Less & More & Less & More & Less & More \\
& & sticker & Sticker & sticker & Sticker & sticker & Sticker \\
Soil type & Nitisol & & Nitisol & Planosol & \\
Vegetation & & Maize, potatoes, & Maize, potatoes, & Scattred shrubs/trees; \\
Water Table & beans, trees & beans, trees & maize,; potatoes \\
\hline
\end{tabular}

Source of the critical values: NAIAAP (2014). Chemical analysis was done according to Mehlich 3 procedures. 


\subsection{Influence of Phosphorus on Potato Tuber Seed Yield (Akoto et al, 2020 below Refers to "Ware" Potato Paper)}

At Saboti, there was a significant difference $(\mathrm{p}=0.045)$ between the seed potato yield of Shangi $\left(22.3 \mathrm{tha}^{-1}\right)$ and Unica $\left(14.4 \mathrm{t} \mathrm{ha}^{-1}\right)$. Interaction between phosphorus rate and variety also significantly $(\mathrm{p}<0.001)$ influenced seed potato yield (Table 5). Among the three test sites, it is only Saboti that had a negative correlation between phosphorus rate and the yield of the seed tubers. This could be a result of natural high soil phosphorus and build-up of soil phosphorus due to previous continuous use of phosphorus fertilizers for maize. Therefore, the analysis of the "ware" fraction of the harvest is deliberately included (Figure $2 \& 3$ ) to sufficiently explain this unique scenario. This analysis indicates that interaction between phosphorus rate and variety significantly $(\mathrm{p}=$ 0.005) influenced "ware" tuber yield. Correlation between phosphorus rate and "ware" potato tuber yields of Shangi $(\mathrm{r}=+0.6) /$ Unica $(\mathrm{r}=+0.7)$ was positive (Akoto et al., 2020). To the contrary, correlation between phosphorus rate and seed tuber yield of Shangi $(r=-0.2) /$ Unica $(r=-0.6)$ was negative (Figure $2 \& 3)$. Apparently, as phosphorus rate increased, the potential seed potato tubers overgrew and became "ware" potato tubers instead. Unica's highest seed tuber yield $\left(33.3 \mathrm{t} \mathrm{ha}^{-1}\right)$ was realized without phosphorus fertilizer. Shangi's highest seed tuber yield $\left(33.7 \mathrm{t} \mathrm{ha}^{-1}\right)$ was realized without both phosphorus and basal nitrogen fertilizers. In contrast, highest yield of Shangi's $\left(19.6 \mathrm{t} \mathrm{ha}^{-1}\right)$ and Unica's $\left(40.5 \mathrm{t} \mathrm{ha}^{-1}\right)$ "ware" potato tubers were realized at 120 and $90 \mathrm{~kg} \mathrm{ha}^{-1}$ phosphorus, respectively (Figure $2 \& 3$ ). Thus, increased fertilizer application enhanced "ware" potato yield at the expense of seed potato yield. Although soil available phosphorus was adequate (45 ppm Mehlich 3 or 57.5 ppm Bray 2) at Saboti for Shangi's and Unica's seed potato tuber yields, it was not so for the "ware" potato tuber yields of the two varieties. This is further explained by less negative $(r=-0.2)$ and more negative $(r=-0.6)$ correlation between phosphorus rate and Shangi's and between the same rate and Unica's seed tuber yields, respectively. Thus, more of Unica's than Shangi's potential seed potato tubers converted to "ware" potato tubers. Similar studies done by Khalid et al., 2003 on potato showed that different varieties of potatoes yielded differently in response to phosphorus application. From studies done in Ethiopia by Israel et al., 2012 on the influence of nitrogen and phosphorus on potato production, it was found that phosphorus rate of $60 \mathrm{~kg} \mathrm{ha}^{-1}$ and nitrogen rate of $165 \mathrm{~kg} \mathrm{ha}^{-1}$ gave optimum yields. Studies by Allison et al., 2001 in the Rift Valley region of Kenya found declining response to phosphorus with its increasing application rates. These findings are also supported by guidelines for seed potato certification and production by KEPHIS, 2016 that observes that seed potatoes may require lesser fertilizer application than "ware" potatoes due to their short maturation period and smaller sizes.

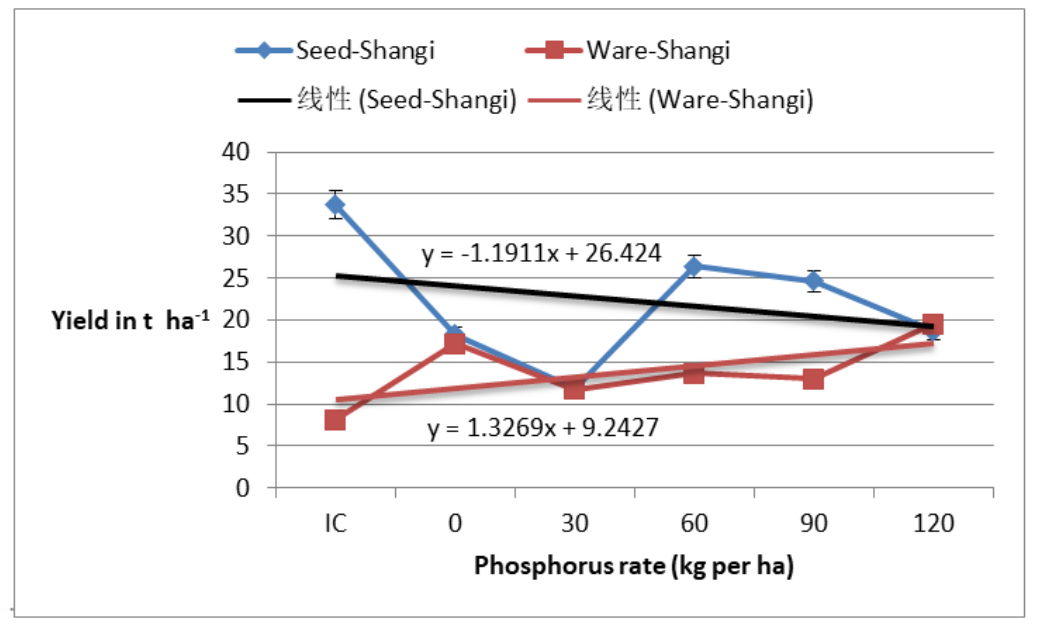

Figure 2. Shangi's seed and "ware" seed potato tuber yield in Saboti (The error bars are percentage (5\%) 


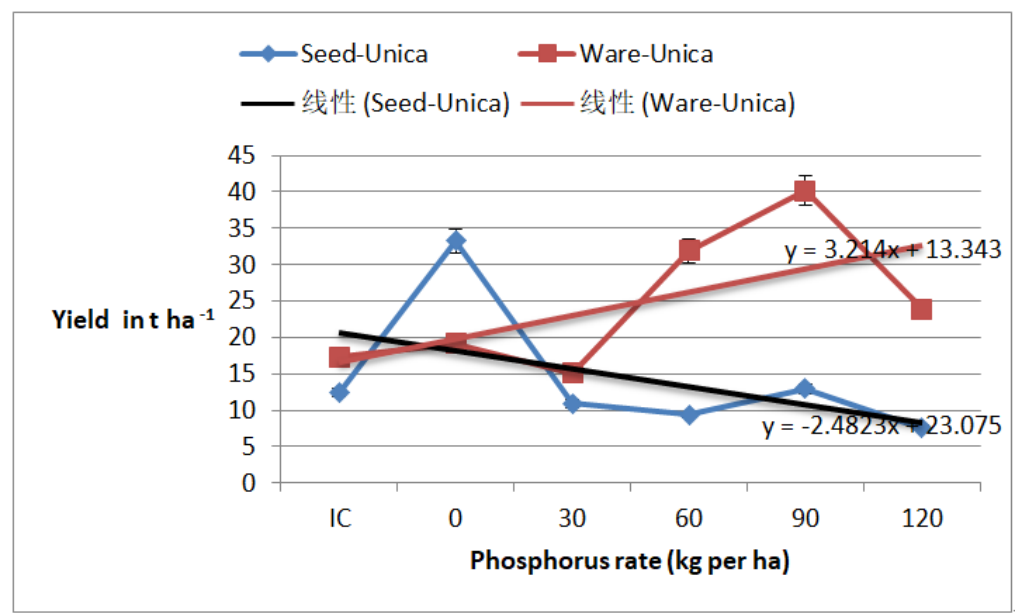

Figure 3. Unica's seed and "ware" potato seed potato tuber yield in Saboti (The error bars are percentage (5\%)

At Ainabkoi, interaction between phosphorus and variety significantly $(\mathrm{p}=0.026)$ influenced seed potato tuber yield. Highest yields of Shangi and Unica were realized at phosphorus rate of $60 \mathrm{~kg} \mathrm{ha}^{-1}\left(20.0 \mathrm{tha}^{-1}\right)$ and $30 \mathrm{~kg}$ $\mathrm{ha}^{-1}\left(18.9 \mathrm{t} \mathrm{ha}^{-1}\right)$, respectively. Correlation between phosphorus rate and Shangi's seed tuber yield and between phosphorus rate and unica's seed tuber yield were +0.7 and +0.3 , respectively (Table 5). As much as soil test results for soil samples taken at planting indicated that there was sufficient soil available phosphorus (40 ppm Mehlich 3 phosphorus) to support the potato crop, there is need for additional phosphorus. This could be a result of the swallow roots of potatoes not being able to extract all the available soil phosphorus in the soil profile (KEHIS, 2016). This also explains why some farmers in Ainabkoi apply phopshorus and nitrogen fertilizer on potatoes. From their experience, they have known that potatoes respond to phosphorus and nitrogen fertilizers. Similar studies have shown that phosphorus rate may or not influence potato tuber yield (Zalalem et al., 2009). Carl et al., 2014 notes scenarios where potatoes responded to fertilizer phosphorus where Mehlich 3 or Bray 2 soil available phosphorus was greater than $100 \mathrm{ppm}$. They have also noted that potatoes have responded to fertilizer phosphorus application of more than $66 \mathrm{~kg} \mathrm{ha}^{-1}$ phosphorus in high phosphorus soils.

At Lari, there was significant difference $(\mathrm{p}=0.010)$ between the mean seed tuber yields of Shangi $\left(15.1 \mathrm{t} \mathrm{ha}^{-1}\right)$ and Unica $\left(7.6 \mathrm{t} \mathrm{ha}^{-1}\right)$. Phosphorus rate significantly $(\mathrm{p}<0.001)$ influenced seed potato yield. Interaction between phosphorus rate and variety significantly $(\mathrm{p}=0.004)$ influenced seed potato tuber yield (Table 5$)$. The initial soil available phosphorus at this site was below the critical level of (30 ppm Mehlich phosphorus). At planting, the area was surrounded with maize that was purplish in colour confirming low soil available phosphorus. The water table of the site was high (1-3 m) necessitating construction and maintenance of drainage channels. There were indications of illuviation as the colour of the top soil was greyish brown. Correlation between phosphorus rate and Shangi's seed tuber yield $(r=+0.9)$ was very strong while the correlation between the same rate and Unica's seed tuber yield was average $(\mathrm{r}=+0.4)$. Shangi and Unica needed 60 and $90 \mathrm{~kg} \mathrm{ha}^{-1}$ phosphorus to produce highest seed potato tuber yields of $19.0 \mathrm{t} \mathrm{ha}^{-1}$ and $10.4 \mathrm{t} \mathrm{ha}^{-1}$, respectively. In a similar study conducted by Zelalem et al., 2009 in the Central highlands of Ethiopia, phosphorus application of $20 \mathrm{~kg} \mathrm{ha}^{-1}$ was optimum for potato production. Israel et al., 2012 found that phosphorus application of $60 \mathrm{~kg} \mathrm{ha}^{-1}$ was needed for optimum yields. From Birturkan (2016), phosphorus needed for optimum potato production was $135 \mathrm{~kg} \mathrm{ha}^{-1}$. This is confirmed by Ekelorf (2007) who has said that there are several factors that contribute to fertilizer recommendations on potatoes which include soil type, nutrient availability, economic factors of an area, moisture supply and variety. It is therefore important to base crop fertilizer requirements on soil test results (Yara International, 2019). Further, while potatoes are very responsive to fresh soil phosphate, the economic optimum rate is not easy to define and hence rates will depend on soil type and soil test results (Yara International, 2016).

Carl et al. (2014) has observed that many soils (like at Lari) lack sufficient phosphorus to optimise potato growth, hence phosphorus fertilization is critical. Phosphorus plays an important function in plant metabolism through its role in cellular energy transfer, respiration and photosynthesis (Ozanne, 1980). Potato has high phosphorus demand and it is generally considered inefficient in taking soil phosphorus (Pursglove and Sanders, 1981). This explains why application of up to $90 \mathrm{~kg} \mathrm{ha}^{-1}$ phosphorus maximized seed potato yield in the current study and why Birturkan, 2016 recommended $135 \mathrm{~kg} \mathrm{ha}^{-1}$ for optimum potato production. Phosphorus is a structural 
component of phosphor-lipids nucleic acids, coenzymes and phosphor-proteins and helps to store nutrients in seeds as phylic acid (Bundy et al., 2005). It influences tuber yields by influencing tuber set, tuber growth rate and duration of tuber growth (Dyson and Watson, 1971). Phosphorus also hastens crop maturity (Stark and Love, 2003). Its uptake is heavily correlated with its status in the soil (Kunkel, 1973). This concurs with the current findings where correlation between potato plant phosphorus and soil phosphorus was very high (Figure 4 and 5) Potatoes take a lot of phosphorus in their growth cycle. Russet Barbank has been found to take 37.4 to $49.6 \mathrm{~kg}$ phosphorus ha ${ }^{-1}$ for yields of 63 to $77 \mathrm{t} \mathrm{ha}^{-1}$ (Mohr and Tomasiewiez (2011). The primary mechanism of phosphorus movement to plant roots is diffusion (Barber's, 1980). In highly acidic soils (like Lari) efficient utilization of phosphorus can be limited by its precipitation in form of orthophosphate aluminium complexes. This may have contributed to the low yields realized at Lari.

Table 5. Influence of phosphorus on yield of seed potato tubers at the test sites

\begin{tabular}{|c|c|c|c|c|c|c|c|c|c|}
\hline \multirow[t]{3}{*}{ P-rate $\left(\mathrm{kg} \mathrm{ha}^{-1}\right)$} & \multicolumn{9}{|c|}{ Mean yield $\left(\mathrm{t} \mathrm{ha}^{-1}\right)$} \\
\hline & \multicolumn{3}{|l|}{ Saboti } & \multicolumn{3}{|c|}{ Ainabkoi } & \multicolumn{3}{|l|}{ Lari } \\
\hline & Shangi & Unic: & Mean & Shangi & Unica & Mean & Shangi & Unica & Mean \\
\hline IC & 33.7 & 12.4 & 23.1 & 12.9 & 12.7 & 12.8 & 5.0 & 7.0 & 6.0 \\
\hline 0 & 18.3 & 33.3 & 25.8 & 16.3 & 15.6 & 16.0 & 10.9 & 6.0 & 8.5 \\
\hline 30 & 11.9 & 10.9 & 11.4 & 13.2 & 18.9 & 16.1 & 15.2 & 7.0 & 11.1 \\
\hline 60 & 26.4 & 9.3 & 17.9 & 20.0 & 8.9 & 14.5 & 19.0 & 8.5 & 13.8 \\
\hline 90 & 24.6 & 12.9 & 18.8 & 18.1 & 19.7 & 18.9 & 20.1 & 10.4 & 15.3 \\
\hline 120 & 18.7 & 7.5 & 13.1 & 18.3 & 17.2 & 17.7 & 20.6 & 6.5 & 13.5 \\
\hline \multirow[t]{6}{*}{ Mean } & 22.3 & 14.4 & 18.3 & 16.5 & 15.45 & 16.0 & 15.1 & 7.6 & 11.4 \\
\hline & \multirow{2}{*}{\multicolumn{3}{|c|}{$\begin{array}{l}\mathbf{L S D}_{\mathbf{p}=\mathbf{0 . 0 5}} \\
=7.4\end{array}$}} & \multirow{2}{*}{\multicolumn{3}{|c|}{$\operatorname{LSD}_{p=0.05}$}} & \multicolumn{3}{|r|}{$\operatorname{LSD}_{p=0.05}$} \\
\hline & & & & & & & Variety & & $=3.2$ \\
\hline & \multirow{3}{*}{\multicolumn{2}{|c|}{$\begin{array}{l}\text { Phosphorus rate } \\
\text { Variety * } \\
\text { Phosphorus rate }\end{array}$}} & \multirow{3}{*}{$\begin{array}{l}=4.7 \\
=7.2\end{array}$} & \multirow{3}{*}{\multicolumn{2}{|c|}{$\begin{array}{l}\text { Phosphorus rate } \\
\text { Variety* } \\
\text { Phosphorus rate }\end{array}$}} & \multirow{3}{*}{$\begin{array}{l}=4.5 \\
=6.1\end{array}$} & \multirow{2}{*}{\multicolumn{2}{|c|}{$\begin{array}{l}\text { Phosphorus rate } \\
\text { Variety* }\end{array}$}} & $=3.7$ \\
\hline & & & & & & & & & \\
\hline & & & & & & & Phosph & rate & \\
\hline CV \% & \multicolumn{3}{|l|}{$21.3 \%$} & \multicolumn{3}{|l|}{$23.5 \%$} & \multicolumn{3}{|l|}{$27.0 \%$} \\
\hline
\end{tabular}

\subsection{Influence of Phosphorus on Potato Seed Quality}

\subsubsection{Influence of Phosphorus on Seed Tuber Specific Density}

At Saboti, phosphorus rate significantly $(\mathrm{p}<0.001)$ and inversely $(\mathrm{r}=-0.59)$ influenced seed tuber specific density. Interaction between phosphorus and variety significantly influenced $(\mathrm{p}<0.001)$ seed tuber specific density. There was also negative correlation between phosphorus rate and seed tuber specific density of Shangi $(r$ $=-0.11) /$ Unica $(\mathrm{r}=-0.46)$ (Table 6$)$. The seed tuber specific density is directly related to its dry matter content (Gould, 1995).The mean seed tuber specific density of Unica (1.06111) was not statistically different ( $\mathrm{p}=0.074)$ from that of Shangi (1.05444). Thus, the two varieties had the same dry matter content. From NPCK (2019), the dry matter content of Shangi (21.4\%) and Unica (21.0\%) are the same. Correlation between phosphorus rate and the seed tuber specific density of Shangi $(r=-0.3) /$ Unica $(r=-0.5)$ was negative. Unica maximized its tuber specific density (1.085) at $30 \mathrm{~kg} \mathrm{ha}^{-1}$ phosphorus while Shangi maximized the same (1.060) without phosphorus fertilizer. Generally, increased phosphorus application above $30 \mathrm{~kg} \mathrm{ha}^{-1}$ in Saboti was detrimental to the seed potatoes' tuber specific density. Over fertilizing can result in lower specific gravities in tubers (DPIRD, 2019). Human (1961) reported an increase in tuber specific density in response to an increase in applied phosphorus while Sparrow et al. (1992) noted non-significant influence in percent dry matter of tubers due to similar application. At planting time zinc was low (25 ppm Mehlich phosphorus) at Saboti. This may have contributed to phosphorus having more influence on the tuber specific density of unica variety in the same site since the uptake mechanism and the role of zinc and phosphorus are similar (Jackson and Carter, 1976). Mailer et al., 1989 in his studies on potatoes noted that phosphorus, site and their interactions significantly affected potatoes' specific density. In his studies on potato, Freeman et al., 1998 noted some cases where the phosphate fertilizer reduced potato tuber specific density.

The findings on specific density at Lari and Ainabkoi are similar in some aspects. At Ainabkoi, there was significant difference $(\mathrm{p}=0.014)$ between seed tuber specific density of Shangi (1.0542) and Unica (1.0447). Phosphorus rate had significant $(\mathrm{p}<0.001)$ influence on seed tuber specific density. Interaction between phosphorus rate and variety significantly $(\mathrm{p}<0.001)$ influenced seed tuber specific density with highest seed tuber specific density of both Shangi (1.0608) and Unica (1.0772) being realized at phosphorus rate of $120 \mathrm{~kg}$ 
$\mathrm{ha}^{-1}$. Correlation between phosphorus rate and seed tuber specific density of Shangi $(\mathrm{r}=+0.4) /$ Unica $(\mathrm{r}=+0.7)$ was positive. At Lari, there was significant difference $(p=0.010)$ between specific density of Shangi $(1.0862)$ and Unica (1.0737). Interaction between phosphorus and variety significantly $(\mathrm{p}=0.007)$ influenced seed tuber specific density. Unlike Ainabkoi, phosphorus had no significant $(\mathrm{p}=0.184)$ influence on the specific density of potatoes at this site. Highest specific density of Shangi (1.1018) was realized with phosphorus rate of $120 \mathrm{~kg} \mathrm{ha}^{-1}$ while that of Unica (1.0880) was realized with phosphorus rate of $60 \mathrm{~kg} \mathrm{ha}^{-1}$ (Table 6). There was also a positive correlation between phosphorus rate and seed tuber specific density of Shangi $(r=+0.5) /$ Unica $(r=+0.2)$. This site had low available phosphorus in its soil (25 ppm Mehlic phosphorus) at planting. However it had adequate zinc (8.58 ppm) unlike the other test sites. Zinc has similar functions like phosphorus (Jackson and Carter, 1976). This may have compromised the influence of phosphorus on the dry matter accumulation. The higher specific density of shangi is confirmed by NPCK (2019) that notes the dry matter accumulation of Shangi and Unica tubers to be $21.4 \%$ and $21 \%$, respectively. Zelalem et al., 2009 has noted conflicting findings on the influence of phosphorus on potato's tuber specific density. This may be due to several factors that contribute to potato's tuber specific density like variety and other soil nutrients like zinc which is known to be antagonistic to phosphorus (Jackson and Carter, 1976). From the work published by the Department of Environment and Primary Studies (1995), it is noted that phosphorus is likely to increase tuber specific density. This department further notes that the water-holding capacity, drainage, structure, fertility, and temperature of a soil can all affect dry matter separately, or they can antagonise each other with the result that they can cancel out the benefits of other factors. Mailer et al., 1989 in his studies on potatoes noted that there was significant difference in the specific density of varieties. Also, phosphorus has various effects on tuber quality, since it functions in cell division and synthesis and storage of starch in the tubers (Houghland, 1960) hence, it can increase the size and percentage of dry matter (DM) (indicated by specific density) of the tubers. (Freeman et al., 1998; Rosen et al., 2014). Phosphorus offsets the negative effects of fertilizer nitrogen on tuber specific gravity (Stark and Love, 2003).

Just as observed in the current study, measured effects of phosphorus on tuber density have been noted to be variable (Carl et al., 2014). Findings from Lari site where soil phosphorus levels are low agrees with studies by Terman et al. (1952) that have shown phosphorus to have more effect on tuber specific density. To the contrary, some studies have shown very little impact of phosphorus on specific densities of potato tubers in soils with low levels of phosphorus (Laboski and Kelling, 2007). Other findings indicate that when soil phosphorus levels are high or very high (like in Saboti) phosphorus has very little or negative impact on specific density (Rosen and Bieman (2008); Freeman et al., 1998 \& Redulla et al., 2002).

Table 6. Means of specific density of tuber seed potatoes at the test sites

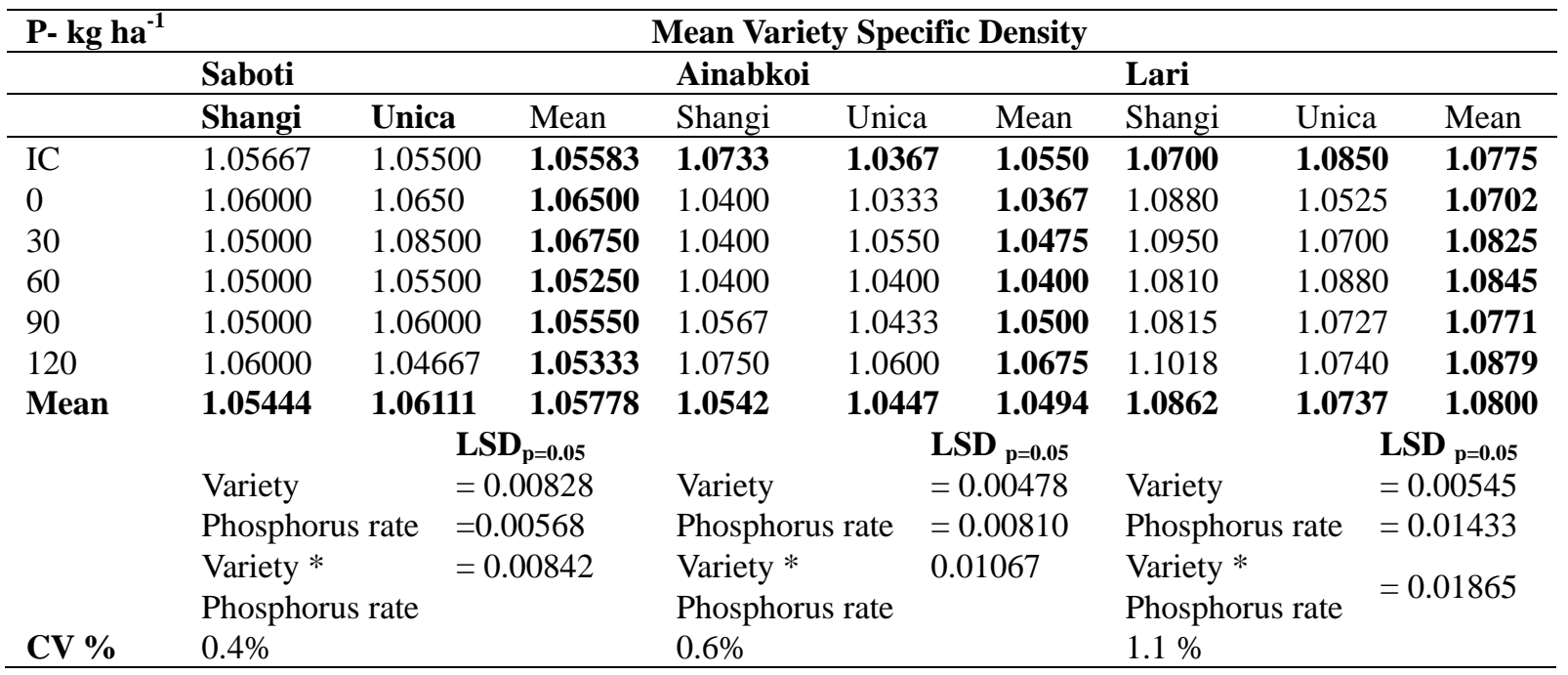

\subsubsection{Influence of Phosphorus on Seed Potato Number of Eyes per Tuber}

At Saboti, there was no significant $(p=0.199)$ difference between the number of eyes per tuber of the test varieties. Further there was no significant influence $(\mathrm{p}=0.117)$ of phosphorus rate on number of eyes per tuber of test seed potatoes. Interaction between phosphorus and variety significantly $(p=0.045)$ influenced number of eyes per tuber. There was a weak positive correlation between phosphorus rate and potato number of eyes per tuber of Shangi $(r=+0.2)$ and Unica $(r=+0.2)$. Seed potatoes whose number of eyes per tuber (Shangi-7 and 
Unica-5) was closer to the recommended range of $4-6$ (KEPHIS, 2016) were found in the treatments without fertilizer nitrogen and phosphorus. Apparently, phosphorus rate affected the tuber size hence the number of eyes per tuber of the potatoes (Table 7).

At Ainabkoi, interaction between phosphorus rate and variety significantly influenced $(p=0.005)$ number of eyes per tuber. There was a significant difference between varieties $(\mathrm{p}=0.034)$ with Shangi's and Unica's number of eyes per tuber being 11 and 9, respectively. Interaction between phosphorus and variety was not significant $(\mathrm{p}=$ 0.191). Treatments without nitrogen and phosphorus fertilizer produced tubers whose number of eyes per tuber (Shangi-10 and Unica-7) was closer to the recommended number of 4 - 6 eyes per seed potato tuber (KEPHIS, 2016). There was a strong negative correlation between phosphorus rate and number of eyes per tuber of Shangi $(\mathrm{r}=-0.6)$ but a weak positive one between phosphorus rate and number of eyes per tuber of Unica $(r=+0.3)$ (Table 7). As much as the number of eyes per tuber is a genetic function that is influenced by variety, the size of a potato and soil nutrients like available phosphorus also influence this number. The number of eyes per tuber increased with its size. Phosphorus rate application negatively influenced $(\mathrm{r}=-0.1)$ the number of eyes per tuber in Ainabkoi. Phosphorus rate also positively influenced the number of potato tubers produced $(r=+0.5)$. Apparently as the phosphorus rate increased, the size and therefore the number of eyes per tuber decreased. The lowest number eyes per tuber were still above the recommended number of four to six (KEPHIS, 2016).

At Lari, phosphorus rate and interaction between it and variety did not have significant $(p>0.050)$ influence on number of eyes per tuber. Thus, Shangi treatments that produced potatoes with number of eyes per tuber closest to the recommended range of four to six were those without any fertilizer. Also, Unica treatments with basal nitrogen fertilizer alone produced potatoes with number of eyes closer to the recommended range (Table 7). At this site, a significant difference $(\mathrm{p}=0.03)$ was noted between varieties. Correlation between phosphorus rate and number of eyes per tuber of Shangi $(r=+0.1)$ was positive while the correlation between the same rate and number of eyes per tuber of Unica $(r=-0.8)$ was negative. Also there was a positive correlation $(r=+0.7)$ between phosphorus rate and number of potato tubers but a negative one $(r=-0.7)$ between the same phosphorus rate and the number of eyes per tuber. The number of eyes per potato tuber is influenced by genetic (like variety) and environmental (like soil available phosphorus) factors (NPCK, 2019).

Potatoes with more than 6 eyes per tuber may be useful as seed if they are sliced to smaller ones, otherwise they may not be economical to plant. If they are sliced, high standards of hygiene and sanitation are required. This may not be within the reach of an ordinary potato farmer who is the end user of potato seed. Potatoes with less than 4 eyes per tuber may be too small for seed. In the event of heavy rainfall, they will tend to rot bringing high losses to farmers. They may also not have enough nutrient reserve to support the young potato seedlings. In their studies on potato seed productivity, Nielson et al., 1989 noted that there was a relationship between a potato tuber size and its number of eyes. Since phosphorus application influenced seed potato tuber's size, it consequently influenced its tuber's number of eyes. Harris (1978) has noted that there is a positive correlation between potato size and number of eyes per tuber in way that the increase in eyes diminishes as the size of the potato increases.

Table 7. Means of the number of eyes per tuber of seed potatoes at Saboti

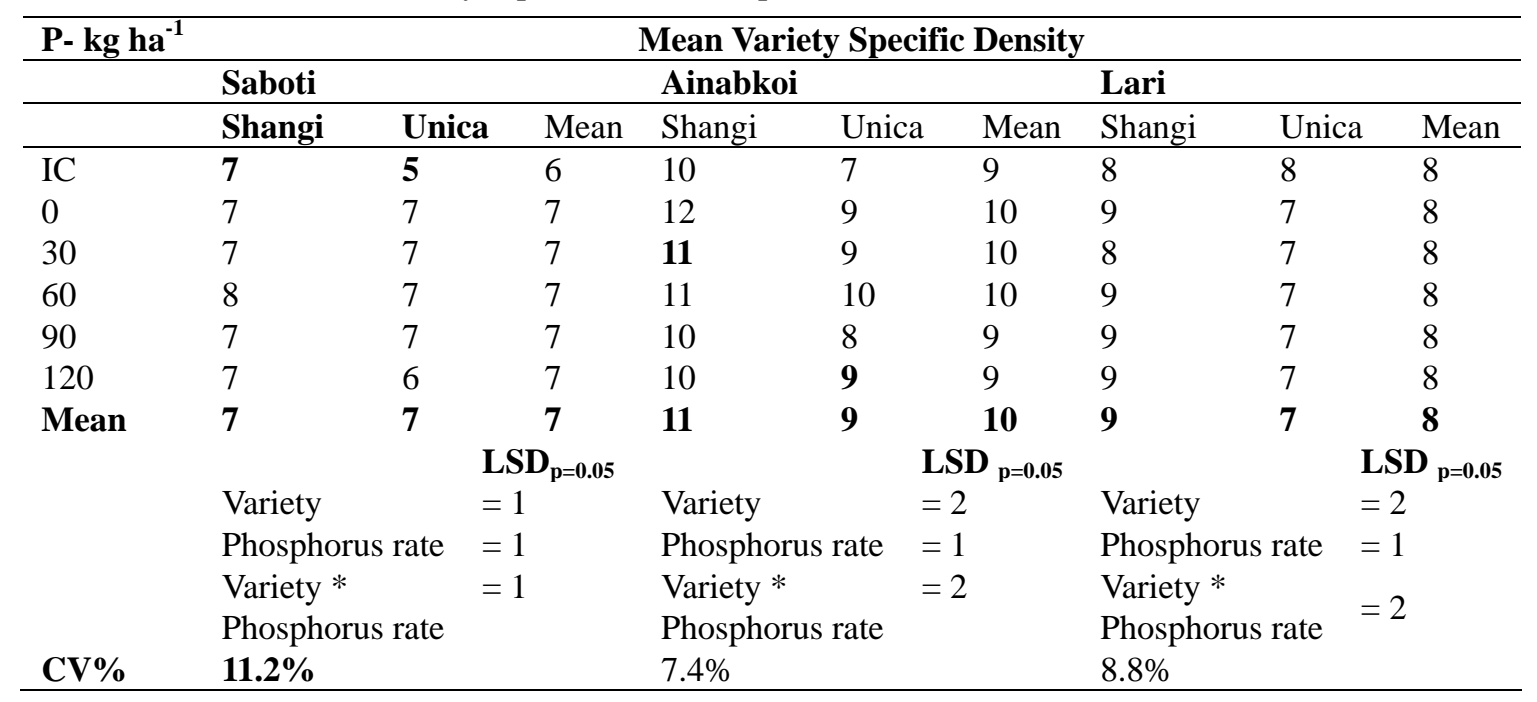

Numbers of eyes in this table have been rounded off to the nearest eye 


\subsubsection{Influence of Phosphorus on Final Germination Percentage (\%)}

The findings at the three test sites were similar in several aspects. At Saboti, phosphorus rate and interaction between it and variety did not significantly $(\mathrm{p}=0.134$ and $\mathrm{p}=0.332$, respectively) influence final germination percentage. There was also no significant difference $(\mathrm{p}=0.390)$ in final germination percentages of varieties. The average final germination percentage of Shangi was $88.9 \%$ while that of Unica was $100 \%$. Correlation between phosphorus rate and mean final germination percentage was positive $(r=+0.5)$. There was also a positive correlation between phosphorus rate and final germination percentage of Shangi $(r=+0.5)$ and Unica $(r$ $=+0.5)$. At Ainabkoi, there was no significant difference $(p>0.05)$ between the final germination percentages of the varieties. Phosphorus rate did not significantly $(p>0.05)$ influence the final germination percentage of the seed potatoes. However, the final germination percentage of Shangi $(88.1 \%)$ was lower than that of Unica (96.1\%).There was a strong positive correlation $(+0.7)$ between phosphorus rate and mean final germination percentage. There was also some correlation between phosphorus rate and final germination percentage of Shangi $(r=+0.05)$ and Unica $(r=+0.5)$. At Lari, results indicate that there was no significant influence $(p>0.05)$ of phosphorus rate, variety and their interaction on final germination percentages of seed potatoes. Also, there was a negative $(\mathrm{r}=-0.6)$ correlation between phosphorus rate and its mean final germination percentage. Correlation between phosphorus rate and final germination percentage of Shangi was negative $(r=-0.7)$. The final germination percentage of Unica (100\%) was higher than that of Shangi (95.7 \%) (Table 8).

In the three test sites, Unica's final germination percentage was greater than Shang's. As much as this difference was not statistically significant, Unica had better coping capacities to climate change impacts which included attacks of pests like aphids and diseases like potato blight. Unica is a new climate smart variety in Kenya that is not only high yielding but also more tolerant to diseases, pests and harsh conditions (like heat and drought) than older varieties (Waikwa, 2018 \& Borus, 2018).

Table 8. Means of final germination percentage (\%) in the test sites

\begin{tabular}{|c|c|c|c|c|c|c|c|c|c|}
\hline \multirow[t]{3}{*}{ P- kg ha $^{-1}$} & \multicolumn{9}{|c|}{ Mean Specific Density } \\
\hline & \multicolumn{3}{|l|}{ Saboti } & \multicolumn{3}{|c|}{ Ainabkoi } & \multicolumn{3}{|l|}{ Lari } \\
\hline & Shangi & Unica & Mean & Shangi & Unic: & Mean & Shangi & Unica & Mean \\
\hline IC & 75.3 & 96.0 & 85.7 & 100 & 83.3 & 91.7 & 100 & 100 & 100 \\
\hline 0 & 81.5 & 100 & 90.8 & 79.6 & 98.1 & 88.9 & 97.2 & 100 & 98.2 \\
\hline 30 & 100 & 100 & 100 & 88.9 & 92.6 & 90.7 & 97.2 & 100 & 98.6 \\
\hline 60 & 88.9 & 100 & 94.5 & 94.4 & 96.3 & 95.4 & 98.1 & 100 & 99.1 \\
\hline 90 & 100 & 100 & 100 & 85.5 & 100 & 92.6 & 87.0 & 100 & 93.5 \\
\hline 120 & 88.9 & 100 & 94.5 & 92.6 & 96.3 & 94.4 & 94.4 & 100 & 97.2 \\
\hline \multirow{2}{*}{ Mean } & 89.1 & 99.3 & 94.2 & 90.1 & 94.4 & 92.3 & 95.7 & 100 & 97.8 \\
\hline & $\begin{array}{l}\text { Phosphorus rate } \\
\text { Variety* } \\
\text { Phosphorus rate }\end{array}$ & \multicolumn{2}{|c|}{$\begin{array}{l}\mathbf{L S D}_{\mathbf{p}=\mathbf{0}} \\
=40.5 \\
=11.7 \\
=30.7 \\
\text { ate }\end{array}$} & $\begin{array}{l}\text { Variety } \\
\text { Phospho } \\
\text { Variety } \\
\text { Phospho } \\
14.0 \%\end{array}$ & rate & $\begin{array}{l}\text { LSD }_{p=0.05} \\
=6.0 \\
=15.6 \\
=20.3\end{array}$ & $\begin{array}{l}\text { Variety } \\
\text { Phosph } \\
\text { Variety } \\
\text { Phosph } \\
6.6 \%\end{array}$ & rate & $\begin{array}{l}\text { LSD }_{\mathbf{p}=\mathbf{0 . 0 5}} \\
=10.6 \\
=7.8 \\
=11.4\end{array}$ \\
\hline
\end{tabular}

\subsubsection{Comparing Seed Potato Tuber Yield with Available Soil and Plant (Tuber) Phosphorus}

There was a perfect correlation $(\mathrm{r}=+1.0)$ between mean seed tuber yield and the soil available phosphorus status at planting. There was also a very strong correlation between soil available phosphorus at planting and the mean seed tuber yield of Shangi $(r=+0.8) /$ Unica $(r=+0.9)$. The mean seed tuber yield at Saboti, Ainabkoi and Lari were $18.3 \mathrm{t} \mathrm{ha}^{-1}, 16.0 \mathrm{t} \mathrm{ha}^{-1}$ and $11.4 \mathrm{t} \mathrm{ha}^{-1}$, respectively while the initial soil available phosphorus (Mehlic 3 ) in the $0-15 \mathrm{~cm}$ in the same sites were $45 \mathrm{ppm}, 40 \mathrm{ppm}$ and $25 \mathrm{ppm}$, respectively (Fig 1). The Bray 2 soil available phosphorus at the sites were 57.7, 43.0 and $20.4 \mathrm{ppm}$, respectively. Soil $\mathrm{pH}$ was directly proportional to the seed potato tuber yield $(\mathrm{r}=+1.0)$. Low soil $\mathrm{pH}$, particularly in Lari may have made many soil micronutrients like manganese to be more available and toxic to the potato plants, hence reducing the seed tuber yields. Despite potatoes being acid "loving", they need moderate to neutral $\mathrm{pH}$ levels of 5.5 to 7.0 to maximize their seed tuber yields (KEPHIS, 2016). Correlation between soil available phosphorus at planting and potato plant tuber phosphorus at harvesting was perfect $(\mathrm{r}=-1.0)$ (Figure $4 \& 5$ ). 


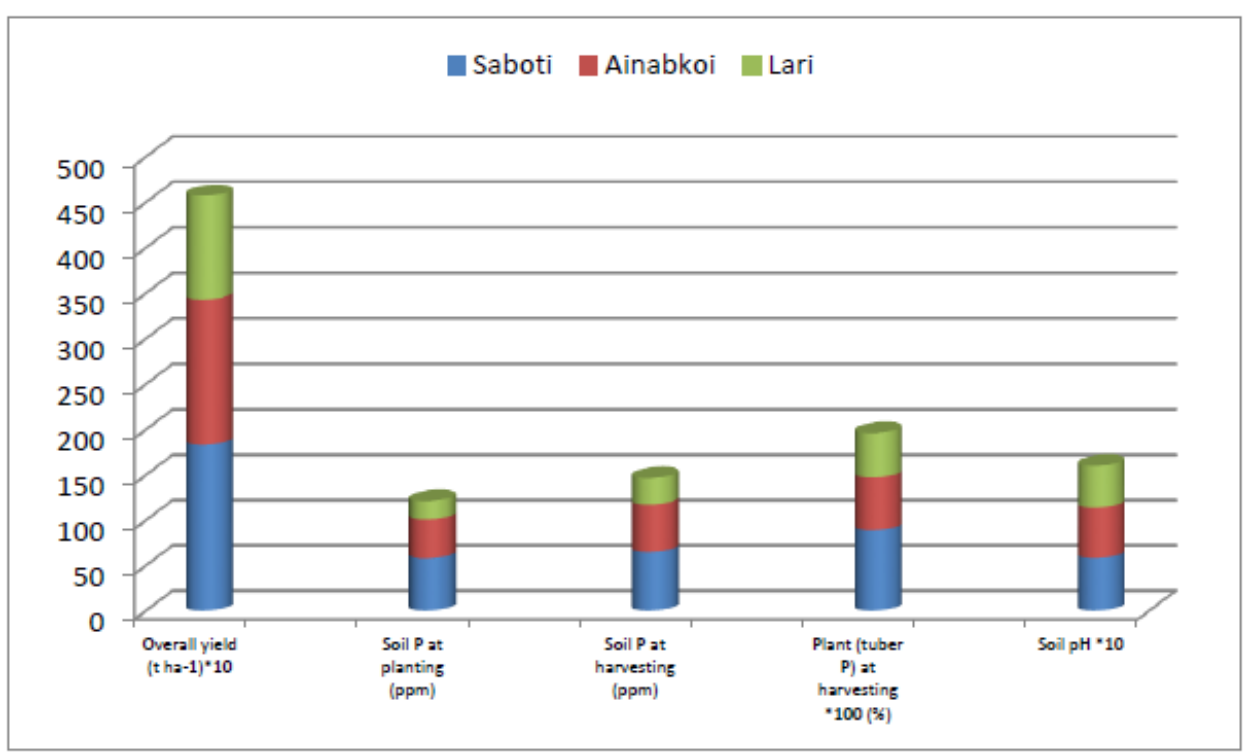

Figure 4. Comparing seed tuber yield with available soil and plant (tuber) phosphorus

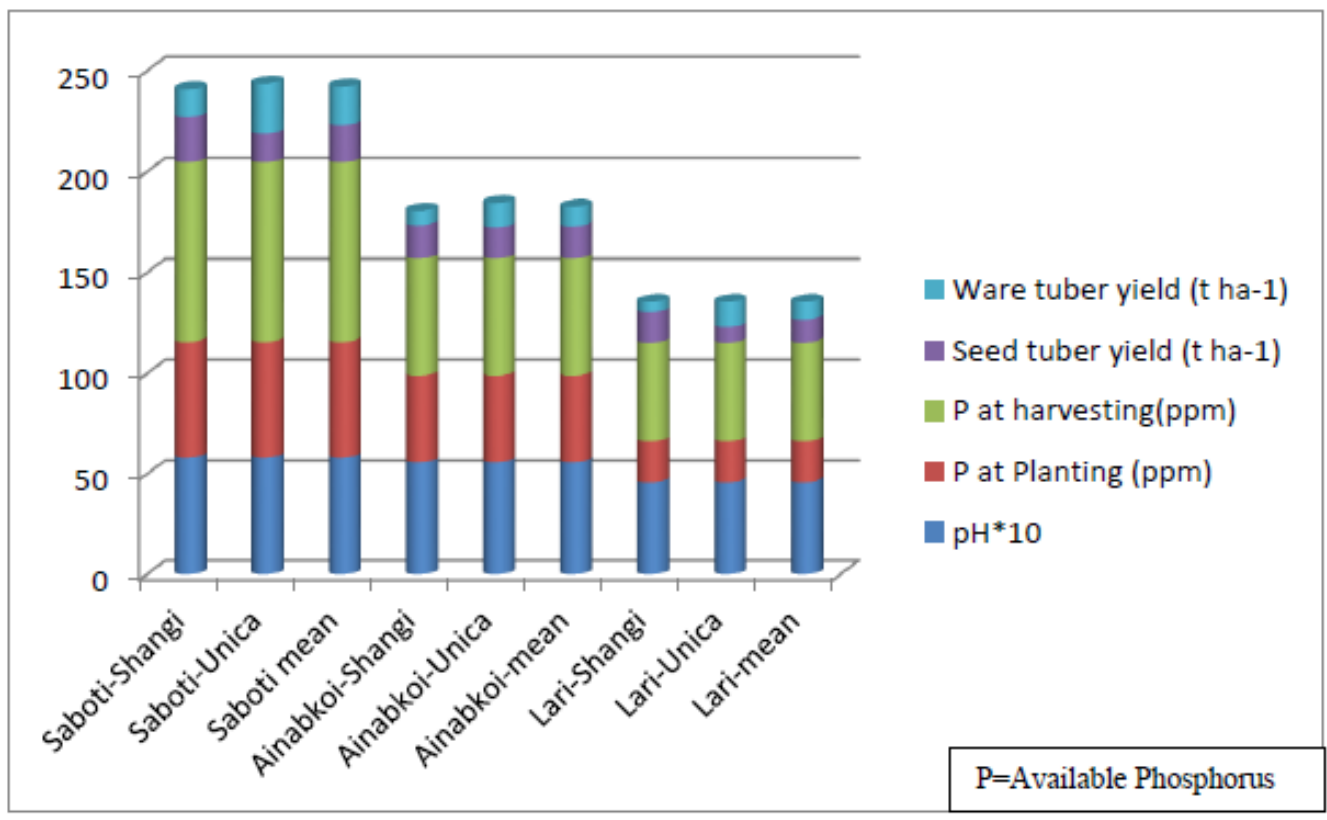

Figure 5. Comparing seed potato tuber yield with "ware" potato yield, available phosphorus and pH

\section{Conclusions}

There were significant influences of phosphorus rates on seed tuber yield. Shangi was more responsive to phosphorus fertilizer rates than Unica. There was a significant correlation between soil available phosphorus at planting and the mean seed potato tuber yield of Shangi and Unica. The phosphorus fertilizer amounts required for highest yields of seed potato tubers were inversely proportional to the same yields. Phosphorus rate significantly influenced specific density of seed potatoes. Unica's resistance to pests and diseases and its final germination percentage were greater than Shangi's. Unica had less number of eyes per tuber than Shangi. The least number of eyes per tuber was realized without nitrogen and phosphorus fertilizers or with basal nitrogen fertilizer alone. Within the seed potato season, there was a build-up of soil available phosphorus. There was significant correlation between mean available soil available phosphorus and mean seed tuber phosphorus. There was also significant correlation between mean soil available phosphorus at planting and at harvesting. There is need for further research on the influence of the combination of phosphorus and nitrogen or nitrogen alone on 
potato seed production in Kenya based on agro-ecological zones and/ or soil types. Further studies are also required on the effect of phosphorus fertilizer application on available soil phosphorus and potato seed sizes in Kenya.

\section{Acknowledgement}

Many thanks to University of Eldoret for invaluable support, Kenyatta University (Statistics Department) for their insightful contributions, National Agricultural Research Laboratories (Kabete) and Kenya Agricultural and Livestock Research Organization (Muguga) for their support in Laboratory analysis. We appreciate Kenya Agricultural and Livestock Rersearch Organization (Tigoni) for their wise counsel. Special thanks to Potato Pesa Project for partially funding the research project. We owe gratitude to the following agricultural officers who participated in this work: Mr. Wachira (Kiambu), Mr. Wasike (Trans Nzoia) and Mr. Wanyike (Uasin Gishu). We are grateful to Paul Nabu (Lari), Franco Khaemba (Saboti) and Sammy Biwot (Ainabkoi) for providing test farms. We appreciate the seed farms belonging to Agricultural Development Cooperation (Molo, Kenya) and Lydia Marindich for availing the seed to plant. Many thanks to Great Mercy Development Centre for their participation in this study, Ruth Chepkemei A. from Mount Kenya University and Grace Vugutsa from Vekaria Construction Company for editing this work. Above all, we thank God for giving us strength to write this paper.

\section{References}

Abong'o, G. O., \& Kabira, J. N. (2013). The current status of potato value chain inKenya, 25-26 may. Trends and opportunities in the production,processing and consumption of staple food crops in Kenya-Conference. : 56-59. Hotel intercontinental, Nairobi. Retrieved from

https://profiles.uonbi.ac.ke/ookogeorge/files/potato_value_chain_abstract_for_staple_food_conf_april_2013 .docx

Agriculture Victoria (2010). Potatoes: Factors affecting dry matter. Retrieved from http://agriculture.vic.gov.au/agriculture/horticulture/vegetables/vegetables-a-z/potatoes/potatoes-factors-affe cting-dry-matter

Akoto, E. M., Caleb, O., \& Ochuodho, J. (2020). The effect of phosphorus fertilizer on the ware potato production in the acid soils of Kenya.University of Eldoret and Ministry of Agriculture, Livestock Development, Fisheries and Cooperatives, Kenya and University of Eldoret 2020.

Allison, J. H., Flower, J. H., \& Allen, E. J. (2001). Effects of soil and foliar applied phosphorus fertilizers on the potato (Solanum tuberosum L) crop. Jagrisci, 137, 379-395. https://doi.org/10.1017/S0021859601001526

Barber, S. A. (1980). Soil-plant interactions in the phosphorus nutrition of plants. In F. E. Khasawneh, E. C. Sample, \& E. J. Kamprath (Eds.), The role of phosphorus in agriculture (591-615). Madison: American Society of Agronomy, Crop Science Society of America and Soil Science Society of America. https://doi.org/10.2134/1980.roleofphosphorus.c22

Birturkan, B. (2016). Effect Of nitrogen and phosphorus rates on growth, yield, yield Components and quality of potato (Solanum Tuberosum L.) at Dedo, South West Ethiopia (Msc). Jimma University, Jimma, Ethiopia.

Borus, D. (2018). Getting seed potato production right. Retrieved from https://www.rtb.cgiar.org/news/getting-seed-potato-production-right

Bundy, L. G., Tunney, H., \& Halverson, A. D. (2005). Agronomic aspects of phosphorus management. In J. T. Sims \& A. N. Sharpley (Eds.), Phosphorus: Agriculture and the environment (685-727). Madison: American Society of Agronomy, Crop Science Society of America, Soil Science Society of America.

Carl, J. R., Keith, A. K., Jeffery, C. S., \& Gregory, A. P. (2014). Optimizing Phosphorus Fertilizer Management in Potato Production. Potato Association of America 2014.

Choudhary, S. K., \& Viji (2016). Retrieved from http://vikaspedia.in/agriculture/agri-Inputs/seeds/seed-quality

Department of Environment and Primary studies. (1995). Potatoes- Factors affecting drymatter. Retrieved from http://agriculture.vic.gov.au/agriculture/horticulture/vegetables/vegetab-les-a-z/potatoes/potatoes-factors-aff ecting-dry-matter

DPIRD. (2019). Department of Primary Industries and Regional Development, Agriculture and Food. Retrieved from https://www.agric.wa.gov.au/potatoes/specific-density-potato-tubers

Duroy, A. N., Aymeric, G., \& Roshani, S. (2009). Nutrition value of potato: vitamin, phytonutrient, and mineral content.

Dyson, P. W., \&Watson, D. J. (1971). An analysis of the effects of nutrient supply on the growth of potato crops. 
Annals of Applied Biology, 69, 47-63. https://doi.org/10.1111/j.1744-7348.1971.tb04657.x

Ekelöf, J. (2007). Potato yield and tuber set as affected by phosphorus fertilization. Master project in the Horticultural Science Programme, 2, 20.

FAO. (2008). Statistics division, 2008. Rome: FAO. Retrieved from http://faostat.fao.org

FAO. ( 2019). Statistics division, 2019. Rome: FAO. Retrieved from http://faostat.fao.org

FAO-UNESCO. (1974). FAO-UNESCO soil map of the world, 1: 5000000 maps and data bases. Retrieved from http://www.fao.org.soil

Freeman, K. L., Franz, P. R., \& Jong, R. W. (1998). Effect of phosphorus on the yield, quality and petiolar phosphorus concentrations of potatoes (cv. Russet Burbank and Kennebec) grown in the krasnozem and duplex soils of Victoria. Australian Journal of Experimental Agriculture, 38, 83-93.

http://dx.doi.org/10.1071/EA96045

ILRI. (2020). GIS International Livestock Research Institute. Retrieved from http://192.156.137.110/gis

Gould, W. A. (1995). Specific density-Its measurement and use. Chipping potato handbook, p. 18-21.

Harova, L. V. M., \& Spejra, R. K. R. (2014). Soil analysis using Mehlich 3 extractant techniques for sample preparation. Teledyne technologies. Retrieved from http://www.teledynecetac.com/resourceSite/Application.Notes/HAM0852.pdf

Human, J. J. (1961). The effect of fertilizer levels on yield and specific density of potatoes. Biological Abstract 39: 278. IAR (Institute of Agricultural Research). 2000. Holetta Guenet Research Station Progress Report, Addis Ababa, Ethiopia.

Harris, P. M. (1978). The potato Crop. The scientific basis for improvement. Department of Agriculture. Springer-Science +Business. Media, B. V.

Houghland, G. V. C. (1960). The influence of phosphorus on the growth and physiology of the potato plant. American Potato Journal, 37, 127-138. http://dx.doi.org/10.1007/BF02855950

Hort (2018). Varieties of certified potatoes grown in Kenya. Hort news growing idears magazine. https://doi.org/10.1055/s-0044-100084

Israel, Z., Ali, M., \& Solomon, T. (2012). Effect of different rates of nitrogen and phosphorus on yield and yield components of potato (Solanum Tuberosum L.) at Masha District, Southwestern Ethiopia. International Journal of Soil Science, 7, 146-156. http://dx.doi.org/10.3923/ijss.2012.146.156

Jackson, T. L., \& Carter, G. E. (1976). Nutrient uptake by Russet Burbank potatoes as influenced by fertilization. Agronomy Journal, 68, 9-12. https://doi.org/10.2134/agronj1976.00021962006800010003x

Jaetzold, R., Schmidt, H., Hornetz, B., \& Shisanya, C. (2011). Farm Management Handbook of Kenya. Vol. II. Natural Conditions and Farm Management Information 2nd Edition Part B. Central Kenya. Subpart B2. Ministry of Agriculture, Nairobi, Kenya.

Jaetzold, R., \& Schmidt, H. (2009). Farm Management Handbook of Kenya. Vol. II/C Kenya. Natural Condition and Farm Management Information. Ministry of Agriculture and German Agricultural Team (GTZ), Nairobi.

Janessens, S. R. M., Wiersema, S. G., Goos, H., \& Wiersma, W. (2013). The value chain forseed and ware potatoes in Kenya. Opportunities for development.

Kaguongo, W. P., Gildemacher, P., Demo, P., Wagoire, W., Kinyae, P., Andrade, J., Forbes, G., Fuglie, K., \& Thiele, G. (2008). Farmer practices and adoption of improved potato varieties in Kenya and Uganda. CIP, Lima, Peru, 5, 42.

Karanja, A. M., Makokha, G. L., \& Shisanya, G. A. (June, 2014). Analysis of the key challenges facing potato farmers in Oljoro-orok Division, Kenya. https://doi.org/10.4236/as.2014.510088

KARI. (2008). Production of food (ware) potatoes. KARI information. Retrieved from www.reportlinker.com/potato

KEPHIS. (2016). KEPHIS Seed Potato Production and Certification Guidelines.

Khalid, D., Mrabet, R., \& Benbouaza, A. E. H. (2003). Responsiveness of different potato (Solanum tuberosum) varieties to Phosphorus fertilizer. 2nd International Symposium on Innovation and Technology in the Phosphate Industry. 
Komen, S. K. (2016). Effect of site, variety and storage environment on yield and quality of seed potato in North Rift of Kenya. Thesis submitted to the graduate school in partial fulfilment of the requirements for the degree of Doctor of Philosophyin Seed Science, School of Agriculture and Biotechnology, University of Eldoret.

Kunkel, R.., Holstad, N., \& Russell, T. S. (1973). Mineral element content of potato plants and tubers vs. yields. American Potato Journal, 50, 275-282. https://doi.org/10.1007/BF02851867

Laboski, C. A. M., \& Kelling, K. A. (2007). Influence of fertilizer management and soil fertility on tuber specific gravity: A review. American Journal of Potato Research, 84, 283-290. https://doi.org/10.1007/BF02986240

Lutaladio, B., Oscar, O., Daniel, C., \& Cain, M. (2009). Sustainable potato production guidelines for developing countries. Food and Agriculture Organization of the United Nations.

Mailer, N. A., Dahlenburg, A. P., \& Williams, C. M. J. (1989). Effect of phosphorus on The Specific Density of Potato Tubers (Solanum Tuberosum L.) Of Cultivars Kennebec and Coliban. Animal Production Science. https://doi.org/10.1071/EA9890869

MOA. (2011). Ministry of Agriculture, Kenya. Field crops technical hand book.

Mohr, R. M., \& Tomasiewicz, D. J. (2011). Effect of phosphorus fertilizer rate on irrigated Russet Burbank potato. Communications in Soil Science and Plant Analysis, 42, 2284-2298. https://doi.org/10.1080/00103624.2011.602457

Muthoni, J. (2016). Soil fertility situation in potato producing Kenyan highlands-case of KALRO-Tigoni. International Journal of horticulture, 6(25), 1-11. https://doi.org/10.5376/ijh.2016.06.0025

NAAIAP. (2014). Soil suitability for growing maize in Kenya. National AgricultureAccelerated Inputs Programme report.

Nielson, M., Iritani, W. M., \& Weiler, L. D. (1989). Potato seed productivity: Factors Influencing eye number per seed piece and subsequent performance. American Potato Journal, 66, 151. https://doi.org/10.1007/BF02853676

NPCK. (2013). National Potatao Council of Kenya potato production manual. Books potato production manual. Retrieved from https://npck.org

NPCK. (2016). National Potato council of Kenya potato variety catalogue booklet K2.

NPCK. (2018). Magazine new 2019. Retrieved from https://npck.org/Magazines/NPCK2018magazineNew2019.pdf

NPCK. (2019). National Potato council of Kenya potato variety catalogue booklet K2.

Okalebo, J. R., Gathua, K. W., \& Woomer, P. L. (2002). Laboratory Methods of Soil and Plant Analysis. A working manual. The second edition.TSBF-CIAT and SACRED.Africa, Kenya.

Open Africa. (2020). Kenya counties- Shape file-Data Sets-openAFRICA. Retrieved from https://open.africa/dataset/kenya-counties-shapefile/resource/0b78f25e-494e-4258-96b8-a3ab2b35b121?inn er_span=True

Ozanne, P. G. (1980). Phosphate nutrition of plants-A general treatise. In F. E. Khasawneh, E. C. Sample \& E. K. Kamprath (Eds.), The role of phosphorus in agriculture (559-589). Madison: American Society of Agronomy, Crop Science Society of America, Soil Science Society of America. https://doi.org/10.2134/1980.roleofphosphorus.c21

Pursglove, J. D., \& Sanders, F. E. (1981). The growth and phosphorus economy of the early potato (Solanum tuberosum). Communications in Soil Science and Plant Analysis, 12, 1105-1121. https://doi.org/10.1080/00103628109367222

Redulla, C. A., Davenport, J. R., Evans, R. G., Hattendorf, M. J., Alva, A. K., \& Boydston, R. A. (2002). Relating potato yield and quality to field scale variability in soil characteristics. American Journal of Potato Research, 79, 317-323. https://doi.org/10.1007/BF02870168

Rodriguez, J. B., Self, J. R., \& Soltanpour, P. N. (1994). Optimal conditions for phosphorus analysis by the ascorbic acid-molybdenum blue method. Soil Sci. Soc. Am. J., 58, 866-870. https://doi.org/10.2136/sssaj1994.03615995005800030034x

Rosen, C. J., Kelling, K. A., Stark, J. C., \& Porter, G. A. (2014). Optimizing Phosphorus Fertilizer Management in Potato Production. American Journal of PotatoResearch, 91, 145-160. 
http://dx.doi.org/10.1007/s12230-014-9371-2

Rosen, C. J., \& Bierman, P. M. (2008). Potato yield and tuber set as affected by phosphorus fertilization. American Journal of Potato Research, 85, 110-120. https://doi.org/10.1007/s12230-008-9001-y

Shawiza, V. (2017). Status of potato farming in Kenya and its contribution to the economy.

Soil Taxonomy. (1975). American Soil classification system by USDA. Natural resources conservation service, Washington DC.

Sparrow, L. A., Chapman, K. S. R., Parsley, D., Hardman, P. R., \& Cullen, B. (1992). Response of potatoes(Solanum tuberosum L. cv. Burbank) to band placed and broadcast high cadmium phosphorus fertilizer on heavily cropped Krasnozems in North-Western Tasmania. Aust. J. Exp. Agri., 32, 113-119. https://doi.org/10.1071/EA9920113

Spooner, D. M., McLean, K., Ramsay, G., Glenn, J., \& Bryan, G. J. (2005). A single domestication for potato based on multiple and amplified fragment length polymorphism genotyping. PNAS, 102(41), 14694-14699. https://doi.org/10.1073/pnas.0507400102

Stark, J. C., \& Love, S. L. (2003). Tuber quality. In J. C. Stark \& S. L. Love (Eds.), Potato production systems (329-343). Moscow: University of Idaho Extension.

Terman, G. L., Hawkins, A., Cunningham, C. E., \& Carpenter, P. N. (1952). Rate, placement and source of phosphorus fertilizers for potatoes in Maine. Maine Agricultural Experiment Station Bulletin no. 506, Orono: University of Maine.

Tuhin, S. R., Takashi, N., \& Mohammed, H. A. (2007). Seed quality as affected by nitrogen and potassium during true potato seed production. Asian Journal of Plant Sciences, 6, 1269-1275. https://doi.org/10.3923/ajps.2007.1269.1275

Waikwa, M. (2018). New generation culture in agriculture. Retrieved from htts://farmers trend.co.ke/newpotato-varieties

Wang, F. (2008). The importance of quality potato in increasing potato production in Asia and Pacific region. Presented in a Workshop to commemorate the international year of the potato. Bangkok, Thailand, 6 May 2008. Retrieved from www.fao.org

Yara International. (2016). Role of phosphate in potato production. Retrieved from http://www.yara.us/agriculture/crops/potato/key-facts/role-of-phosphate/

Yara International. (2019). Potato Crop Nutrition. Role of Phosphorus in Potato Production. Retrieved from https://www.yara.us/crop-nutrition/potato/role-of-phosphorus/

Zelalem, A., Tekalign, T., \& Nigussie, D. (2009). Response of potato (Solanum tuberosum L.) to different rates of nitrogen and phosphorus fertilization on vertisols at Debre Berhan, in the central highlands of Ethiopia. African Journal of Plant Science, 3(2), 016-024. Retrieved from http://www.academicjournals.org/AJPS

\section{Copyrights}

Copyright for this article is retained by the author(s), with first publication rights granted to the journal.

This is an open-access article distributed under the terms and conditions of the Creative Commons Attribution license (http://creativecommons.org/licenses/by/3.0/). 